\title{
A Finite Element Approach to Evaluate Thermoregulation in the Human Body due to the Effects of Sweat Evaporation during Cooking, Cleaning, and Walking
}

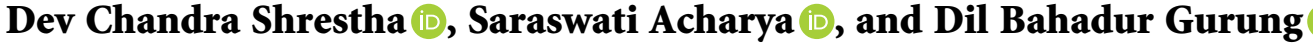 \\ Department of Mathematics, School of Science, Kathmandu University, Dhulikhel, Nepal \\ Correspondence should be addressed to Dev Chandra Shrestha; shresthadev28@yahoo.com
}

Received 17 February 2021; Revised 4 April 2021; Accepted 17 May 2021; Published 27 May 2021

Academic Editor: Babak Shotorban

Copyright (c) 2021 Dev Chandra Shrestha et al. This is an open access article distributed under the Creative Commons Attribution License, which permits unrestricted use, distribution, and reproduction in any medium, provided the original work is properly cited.

\begin{abstract}
Sweat evaporation is the principal process of dissipating heat energy in a hot environment and during activities. Sweat loss is significantly affected by the level of energy expenditure, hormones, and the number of sweat glands. The thickness of the skin layer plays a vital role to maintain body temperature. The rate of sweat evaporation varies with ambient temperature and activity level. On increasing both metabolism and ambient temperature, sweat rate loss also increases and controls the body in the thermoregulatory system. The evaporative sweat release rate has a linear behavior. The appropriate physical and physiological parameters that affect thermoregulation have been incorporated into the model. The study presents the temperature distribution in three layers: epidermis, dermis, and subcutaneous tissue (SST) of the human dermal parts during cooking, cleaning, and walking. The solution is obtained by using the finite element method. The results demonstrate that the body mechanism keeps the body in thermoregulation by increasing the sweat evaporation rate exhibited by increasing the ambient temperature and metabolism during strenuous activities.
\end{abstract}

\section{Background}

Heat dissipation during physical activities is a principal part of thermoregulation in the human body. Generally, the body loses heat by the processes of conduction, convection, radiation, and evaporation through the skin. When the atmospheric temperature equals or exceeds the skin temperature or the body produces more metabolic heat energy, heat loss occurs by radiation, and convection processes are inadequate to control the body temperature. So the hypothalamus, the temperature control room of the brain, becomes active and conveys the signal to different organs such as muscles, glands, and nerves. These organs respond and most of the excess heat loss by the evaporation process, which keeps the body in homeostasis [1].

The water loss from the body by releasing sweat is the amount of evaporating sweat determined by air velocity and the water vapor pressure gradient between skin and atmospheric temperature. The sweat release rate and its regulation depend on the body core, skin temperature, wetted skin area, heat storage, and ambient variables. Clothing, physical activity level, and the number of active eccrine and apocrine glands also play a vital role in sweating. A high sweat rate occurs on the forehead, neck, interior, and posterior parts of the trunk and dorsal surface of the hand and forearm. Low rates occur in the medial femoral region, lateral trunk area, palms, and soles in the human body [2].

Sweating is present and effective in children also, but the high capacity of evaporating heat occurs in an adult due to having more sweat glands [2]. There is no change in the exhale sweat rate in the age group between 18 and 50 years. After 50 years of age, there is a decrement in the sweating response due to the decrease in basal metabolic rate (BMR) [3].

At the rest position, the body produces a negligible sweating amount at the normal environment temperature. It 
loses about $25 \%$ of heat energy in the form of sweat. Each liter of evaporating sweat removes about $580 \mathrm{kcal}$ of heat energy from the body [4]. A healthy body produces approximately $1.94 \mathrm{ml}$ of sweating in a hot moist environment [3]. The sweat release rate from the body is proportional to ambient temperature and metabolic rate. Generally, in a rest lightly clothes person, the sweat starts at $29^{\circ} \mathrm{C}$ while the resting nude person begins it at the environment temperature $31^{\circ} \mathrm{C}$ [5]. In low ambient temperature also, the healthy body releases sweat due to increases in the metabolic rate during the activity.

During the activity period, the metabolic rate increases and produces a large amount of heat energy. If the surplus metabolic heat energy cannot dissipate, it affects the heart in the blood circulation and may lead to stroke or heart attack, indicating thermoregulatory failure in the body. So the excess heat energy is lost through the perspiration process from the skin and controls the body temperature normal. When environment temperature increases, there is a greater dependence on evaporative heat loss to defending the body core temperature. At a high activity period, the body maintains thermal balance to augment evaporative cooling by activating both eccrine and apocrine sweat glands, secrete sweat on the skin surface, and keep the body in thermoregulation. In more hot and humid conditions, although a person sweats heavily, it usually does not feel cold because the sweat cannot evaporate and take latent heat, and it simply drips off the body. Besides, in a dry climate, the sweat generally evaporates, without wetting the skin surface, by the heat supplies on the skin surface, and maintain the body temperature.

Else ways in acclimatization, it is not sure that the higher temperature will always evaporate the sweat. The sweat may start dripping for a person who is not using the warm environment; the body heat transmission through evaporation becomes ineffective. But if the person gets used to the hot environment, he will look drier and feel cold due to evaporative cooling. A high active person acclimatizes heat to produce several liters of sweat per hour and helps to reduce the body temperature and prevents hyperthermia disorder.

The average healthy person has a normal body core temperature between $36.1^{\circ} \mathrm{C}$ and $37.8^{\circ} \mathrm{C}$. It may fall by $2^{\circ} \mathrm{C}$ in the cold environment at rest. During light intensity activities in a hot environment, the average sweating rate is $170.83 \mathrm{ml} /$ hour. But the maximum sweating rate is increased to 3.7 liters per hour for strenuous physical exercise in the same hot environment [3]. It shows that sweat loss is affected significantly by the activity level.

Muscles are the principal source of metabolic heat energy. It may produce up to $90 \%$ of the total metabolic energy of the body in light intensity activities and helps to decrease body weight by increasing the movement of cardiovascular organs [6]. The quantity of muscle mass determines the BMR in the human body. It depends on body surface area, age, gender, and hormones. The average BMR in a healthy human body is $1114 \mathrm{w} / \mathrm{m}^{3}$ [7]. Besides this BMR, the body produces additional metabolic energy during the activity. According to energy expenditure by the body, the estimation value of metabolic rate during walking is $3889.43 \mathrm{w} / \mathrm{m}^{3}$ and during cleaning is $3266.67 \mathrm{w} / \mathrm{m}^{3}$. The scale of metabolic rate during various light activities is presented in Table 1.

Skin is the thermal receptors organ that identifies the environment variables. If any illness occurs in the body, the symptom first shows by changing its temperature. In mathematical treatments of temperature distribution, the skin membrane is regarded as a physical and physiological barrier with a complex structure. Generally, the human body has a different skin thickness, and it depends on the location of the body. So in this model, two skin sets having different thicknesses are taken. Each skin set is divided into the epidermis, dermis, and subcutaneous tissue layers. The overlying outer layer epidermis contains several layers of dead cells. There is no metabolic activity and no blood flow. The middle layer dermis contains the network of blood cells, blood capillaries, lymphatics, nerves, sweat glands having different parameter values dependence on position and tissue temperature. The innermost subcutaneous tissue contains fat and adipose tissue saturates with active cells and blood vessels. Skin responses peripheral vasoconstriction and vasodilation processes refer to a change in blood vessel size which affects its temperature by changing the rate of blood flow. The vasoconstriction process occurs if the skin temperature reduces by low environment temperature. The vasodilation process occurs if the skin has a high temperature to keeps the body temperature normal. The blood flow has a high concentration and metabolic rate increased during activity, which helps to increase the skin layers temperature [9]. These show that the skin temperature is more during activities than at rest.

When the environment temperature changes, the body mechanism works differently and keeps the body in thermoregulation. If the ambient temperature is lower than the body temperature, the body losses heat to the environment. The body maintains temperature by producing heat energy by shivering process in muscles and helps to raise the body temperature. The contribution of heat production by the body core is higher than the contribution of skin, with ratio of about $4: 1$ by shivering, and maintains the body temperature [4]. These show that the body core brings a significant change in skin temperature and change with a small range in body core temperature.

When the surrounding temperature is more than body temperature, the body gains the heat energy from the surrounding. The eccrine sweat glands continuously release a large amount of sweat so, the sweat glands are controlled by the sympathetic nervous system in the body. At ambient temperatures $25^{\circ} \mathrm{C}$, the estimated value of sweat evaporation rate from the body is $24.792 \times 10^{-6} \mathrm{~kg} / \mathrm{m}^{2} \mathrm{~s}$ and $25.410 \times$ $10^{-6} \mathrm{~kg} / \mathrm{m}^{2} \mathrm{~s}$ at rest, and walking, respectively. The scale of sweat rate loss at different ambient temperatures $15^{\circ} \mathrm{C}, 25^{\circ} \mathrm{C}$, $35^{\circ} \mathrm{C}$, and $45^{\circ} \mathrm{C}$ at rest and walking is presented in Table 2 .

Blood perfusion refers to the process of delivery of arteries blood to a capillaries bed in the living tissues. This process works either to dissipate the heat or reheat the cooled area to keep the body temperature normal. Tissue blood flow is the amount of blood flow through the capillaries of the vascular bed of that structure or region. Pennes' 
TABLE 1: Metabolic rate during various activities [8].

\begin{tabular}{lc}
\hline Type of physical activities & Metabolic rate $\left(\mathrm{w} / \mathrm{m}^{3}\right)$ \\
\hline Cooking & 2212.16 \\
Cleaning & 3266.67 \\
Walking & 3889.43 \\
\hline
\end{tabular}

TABLE 2: Sweat evaporation rate at different ambient temperatures at rest and during walking.

\begin{tabular}{lcc}
\hline $\begin{array}{l}\text { Ambient } \\
\text { temperatures }\end{array}$ & $\begin{array}{c}\text { Sweat evaporation } \\
\text { rate at rest }\left(\mathrm{kg} / \mathrm{m}^{2} \mathrm{~s}\right)\end{array}$ & $\begin{array}{c}\text { Sweat evaporation rate } \\
\text { during walking }\left(\mathrm{kg} / \mathrm{m}^{2} \mathrm{~s}\right)\end{array}$ \\
\hline $15^{\circ} \mathrm{C}$ & $17.008 \times 10^{-6}$ & $17.627 \times 10^{-6}$ \\
$25^{\circ} \mathrm{C}$ & $24.792 \times 10^{-6}$ & $25.410 \times 10^{-6}$ \\
$35^{\circ} \mathrm{C}$ & $32.576 \times 10^{-6}$ & $33.190 \times 10^{-6}$ \\
$45^{\circ} \mathrm{C}$ & $40.351 \times 10^{-6}$ & $40.978 \times 10^{-6}$ \\
\hline
\end{tabular}

in 1948 formulated a model by conducting a sequence of experiments measuring temperatures of tissue and arterial blood in the resting human forearm. The rate of heat transfer between blood and local tissue is proportional to the product of a volumetric perfusion rate and temperature gradient between arterial blood temperature and the local tissue temperature [10]. The model is prepared by using the thermal diffusion effect, metabolic rate, and effect of blood perfusion on the energy balance within the tissue. These effects were included in the standard thermal energy conservation equation and modeled as Pennes's bio-heat equation (1).

$$
\rho c \frac{\partial T}{\partial t}=\nabla \cdot(K \nabla T)+\rho_{b} c_{b} w_{b}\left(T_{A}-T\right)+Q_{m}(t),
$$

where

$$
\begin{aligned}
& \rho: \text { tissue density }\left(\mathrm{kg} / \mathrm{m}^{3}\right), \\
& c: \text { tissue specific heat capacity }\left(\mathrm{J} / \mathrm{kg}^{\circ} \mathrm{C}\right), \\
& K \text { : tissue thermal conductivity }\left(\mathrm{w} / \mathrm{m}^{\circ} \mathrm{C}\right), \\
& \rho_{b}: \text { blood density }\left(\mathrm{kg} / \mathrm{m}^{3}\right), \\
& c_{b}: \text { blood specific heat capacity }\left(\mathrm{J} / \mathrm{kg}^{\circ} \mathrm{C}\right), \\
& w_{b}: \text { blood perfusion rate }(/ \mathrm{s} .), \\
& T_{A}: \text { arterial blood temperature }\left({ }^{\circ} \mathrm{C}\right), \\
& T: \text { tissue temperature }\left({ }^{\circ} \mathrm{C}\right), \\
& Q_{m}(t): \text { metabolic heat generation rate }\left(w / \mathrm{m}^{3}\right) .
\end{aligned}
$$

The blood temperature is assumed to be constant arterial blood temperature. The perfusion rate increases highly, and the muscle activities increase slowly during light activities [11].

The development of the temperature distribution model in the past period was mainly based without considering the layers of dermal parts. No models of metabolic rate during activity are presented. But nowadays, the rapid development of information and computer technology made it easy for the researcher to model the temperature distribution of the human dermal parts by dividing it into several layers. There is continuous development for constructing the thermal models in the formulation of heat transfer in living tissues after the investigation of the bio-heat equation by Pennes'.

Gurung and Acharya [1] studied the sweat releasing rate in males and females. The result showed that the sweat releasing rate in the female is lower than male due to the lower density of sweat glands and hormones in the female. Nadel et al. [12] studied the relation between the body core, skin temperature, and sweat evaporation in the body. They suggested that sweat rate is proportional to the gradient temperature between the body core and skin temperatures. Saxena and Arya [13] have studied the steady-state temperature distribution in the skin and subcutaneous tissue (SST). They considered the three layers, epidermis, dermis, and subcutaneous tissue of the SST region by assuming that skin is exposed to a dry and cool environment with negligible perspiration. The authors used the different values of physiological parameters in this model. Gurung et al. [14] investigated the finite element method approach to onedimensional unsteady state temperature distribution in human dermal parts with quadratic shape function. The authors developed the model of temperature distribution in skin three layers, namely, epidermis, dermis, and underlying tissue layer. In this model, they assumed that the outer skin is exposed to the atmosphere and heat loss occurs due to convection radiation and evaporation of water.

Acharya et al. [15] divided the dermal part into six skin layers and studied the metabolic effect in thermoregulation on human males and females. Agrawal [8] and Kenefick et al. [16] experimentally investigated the amount of energy expenditure during cooking, cleaning, and walking. Khanday and Saxena [17] studied the thermoregulation in the human head exposed in a cold environment. The model incorporates biochemical reactions concerning heat generation, blood circulation, and other biophysical activities. Agrawal et al. [18] established a model in a human limb for the temperature distribution by assuming an irregular tapered shaped limb with a different radius and eccentricity. Saxena and Arya [13] and Saxena and Gupta [19] published the papers on the effect of blood flow and heat flow in human skin and subcutaneous tissue by using variational finite element method. Kumari and Adlakha [20] made a mathematical model and investigated the temperature distribution in human peripheral regions including the blood mass flow rate, thermal conductivity, and metabolic heat generation rate which are constants during and after the exercise. Numerous researchers developed the model by using the constant metabolic rate and provided the temperature profile of different skin layers in human dermal parts. So this research paper is studying the temperature distribution in human dermal parts due to the sweating effect, carried out by various activities.

The finite element method is used for the discretization of the domain. Since the SST region of the human body is neither smooth nor rough to each other, the layers in the SST region may be of irregular shapes also. So, it is challenging to obtain the exact solution to heat transfer. The finite element method provides the guideline to divide the whole region 
into a finite number of elements and assemble the results. The FEM also provides all the elements in the symmetric matrices form and converges to the exact solution. The accuracy of the solution increases if the number of elements is increasing. Thus, this technique is a suitable numerical method to find the approximation solution for the temperature distribution on the dermal region under any atmospheric conditions.

\section{Mathematical Model}

2.1. Behavior of Metabolic Energy. The metabolic rate increases due to an increase in the rate of blood flow. The continuous increase in blood flow is controlled by the body mechanism rapidly producing metabolic energy at the beginning of the activity and becomes constant after a certain time. Thus, the metabolic rate shows the logical behavior during activities. We consider the metabolic rate $Q_{m}(t)$ equation based on activity as

$$
Q_{m}(t)=Q_{0}+\frac{A-Q_{0}}{1+e^{-\alpha\left(t-t_{s}\right)}},
$$

where $Q_{0}$ is the basal metabolic rate, $t$ is activity period, $A$ is activity threshold metabolism, $\alpha$ is an activity-controlled parameter per unit time, and $t_{s}$ is the Sigmoid's midpoint of the curve over time $t$ for extensive exercise.

Figure 1 represents the unsteady behavior of metabolic rates of the normal human body during the various activities in the 1800 seconds (half-hour) period. In the normal human body, the body core temperature ranges between $36.1^{\circ} \mathrm{C}$ and $37.2^{\circ} \mathrm{C}$. The figure shows the threshold metabolic value during the cooking is $2212.16 \mathrm{w} / \mathrm{m}^{3}$, during cleaning is $3266.67 \mathrm{w} / \mathrm{m}^{3}$, and during walking is $3889.43 \mathrm{w} / \mathrm{m}^{3}$ at $\alpha=0.01 / \mathrm{sec}$, and $t_{s}=500 \mathrm{sec}$ with BMR $=1114 \mathrm{w} / \mathrm{m}^{3}$.

2.2. Behavior of Sweat Evaporation. The sweat evaporation in the body depends on skin temperature. The skin temperature also depends on the level of activity and ambient temperature. At a high ambient temperature and high metabolic rate, the body produces more sweat than in low ambient temperature and at rest. This shows that the rate of sweat evaporation is increased by increasing the ambient temperature and have linear behavior. The sweat evaporation rate $\left(E_{\mathrm{st}}\right)$ equation is based on the ambient temperature as

$$
E_{\mathrm{st}}=8.47 \times 10^{-5}\left[\left(0.1 \times T_{\mathrm{st}}+0.9 \times T_{b}\right)-36.6\right] .
$$

The symbol $T_{\text {st }}$ in equation (4) is the skin surface temperature which depends on the ambient temperature and $T_{b}=37^{\circ} \mathrm{C}$ is the body core temperature [21]. Figure 2 represents the behavior of sweat evaporation rate at rest and during walking at ambient temperatures $15^{\circ} \mathrm{C}, 25^{\circ} \mathrm{C}$, $35^{\circ} \mathrm{C}$, and $45^{\circ} \mathrm{C}$. The data of sweat rates are taken from Table 2.

\section{Modified Bioheat Equation}

The formulated bio-heat transfer model equation established by Pennes' [10] and Perl [22] describes the effect of

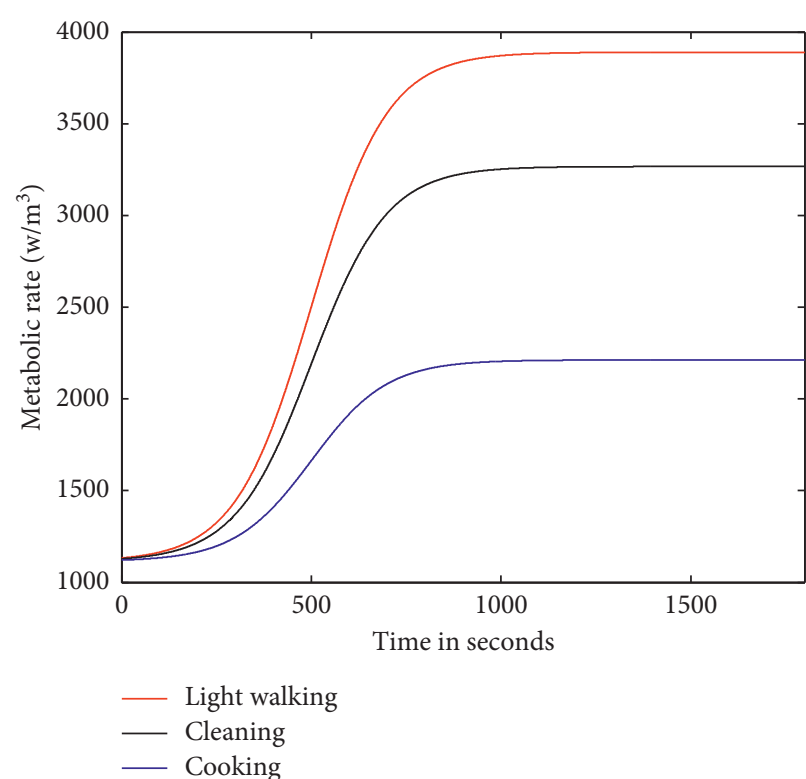

Figure 1: Metabolic rate behavior during different activities.

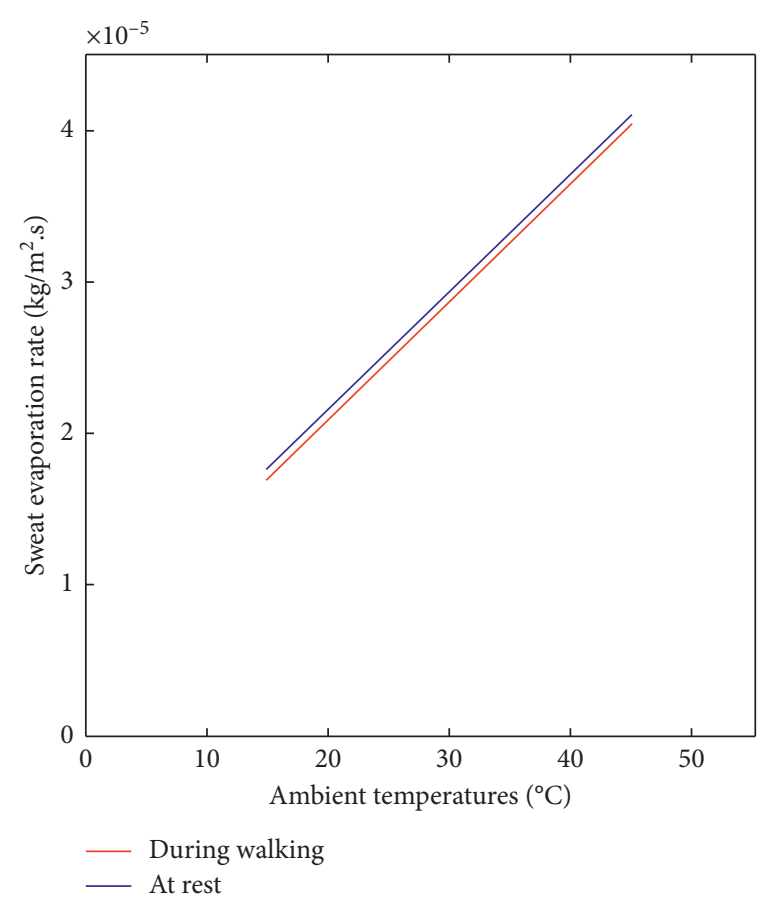

FIgURE 2: Sweat evaporation rate at rest and during walking at various ambient temperatures.

conduction, perfusion, and metabolism in the human tissue. During the activity period, the surplus metabolic heat energy arises and dissipates from the body to the environment by its mechanism. The resulting bio-heat equation with metabolic energy is modified by

$$
\rho c \frac{\partial T}{\partial t}=\nabla \cdot(K \nabla T)+\rho_{b} c_{b} w_{b}\left(T_{A}-T\right)+\left(Q_{0}+\frac{A-Q_{0}}{1+e^{-\alpha\left(t-t_{s}\right)}}\right) .
$$




\section{Solution of the Model}

4.1. Discretization. Skin is the largest organ of the body and has several functions. It forms a physical barrier to the environment, allowing and limiting the inward and outward passage of water and various substances. It maintains body temperature with the help of various physiological parameters. The thickness of the skin layer is important for controlling body temperature normal. In this study, the thickness of the skin is divided into the epidermis, dermis, and subcutaneous tissue layers. Each layer is measured perpendicularly from the outer skin surface towards the body core. Let $y_{1}, y_{2}$, and $y_{3}$ be the distance of epidermis, dermis, and subcutaneous tissue, respectively, measured from the outer surface of the skin. The thickness of the epidermis is $y_{1}$, the dermis is $y_{2}-y_{1}$, and subcutaneous tissue is $y_{3}-y_{2}$. The schematic diagram of the temperature distribution model in dermal parts of the human body is presented in Figure 3.

Let $T_{0}, T_{1}$, and $T_{2}$ be the nodal temperatures at a distance of $x=0, x=y_{1}, x=y_{2}$, respectively. $T_{3}$ is the body core temperature at a distance of $x=y_{3}$. Let $T^{(0)}, T^{(1)}$, and $T^{(2)}$ be the temperature functions of epidermis, dermis, and subcutaneous tissue, respectively.

The heat regulation in in vivo tissue of human skin layers during various activities is given by the partial differential equation (Pennes' bioheat equation), which can be written for $1 \mathrm{D}$ as

$$
\rho c \frac{\partial T}{\partial t}=\frac{\partial}{\partial x}\left(k \frac{\partial T}{\partial x}\right)+M\left(T_{A}-T\right)+\left(Q_{0}+\frac{A-Q_{0}}{1+e^{-\alpha\left(t-t_{s}\right)}}\right),
$$

where $M=\rho_{b} c_{b} w_{b}\left(\mathrm{~J} / \mathrm{m}^{3 s^{\circ}} \mathrm{C}\right)$.

\subsection{Boundary Conditions}

4.2.1. Boundary Condition at $x=0$ (Skin Surface). The outer surface of the body is exposed to the environment during the activity period. Therefore, heat flux is dissipated for $x=0$ and, heat loss takes place from the outer surface due to conduction, convection, radiation, and evaporation processes. So the net heat flux calculated by Robin's boundary condition changes to

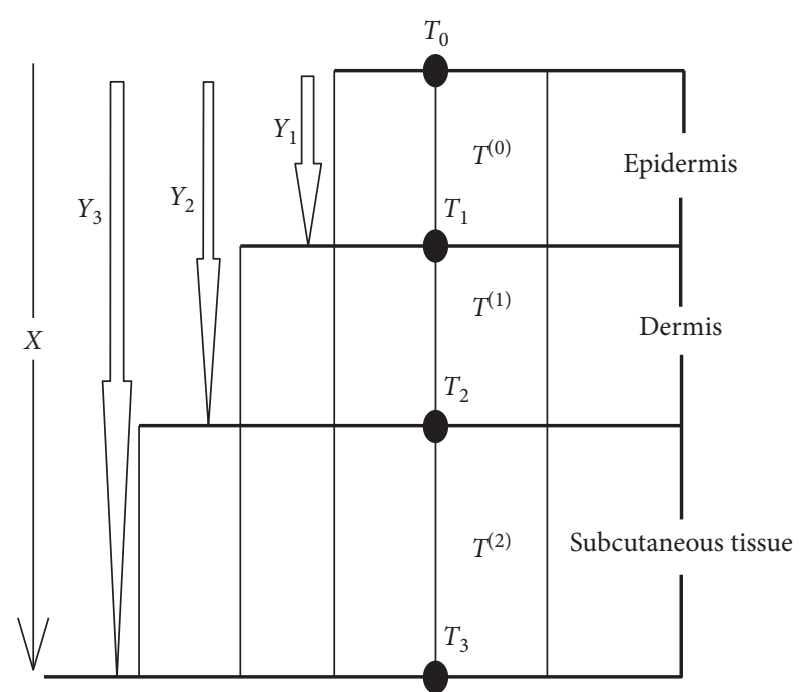

FIgURE 3: Schematic three layers' skin diagram.

$\left.K \frac{\partial T}{\partial x}\right|_{x=0}=h\left(T-T_{\infty}\right)+L\left[8.47 \times 10^{-5}\left(0.1 \times T_{\text {st }}+0.9 \times T_{b}-36.6\right)\right]$,

where $L, h, T_{\infty}$, and $T_{\text {st }}$ are the latent heat capacity, combined heat transfer coefficient due to convection and radiation, ambient temperature, and skin surface temperature, respectively.

4.2.2. Boundary Condition at $x=y_{3}$ (Body Core). During the light activity, due to the slow movement of muscle mass, there is negligible change in metabolic heat energy, so all the metabolic energy dissipates instantaneously at that time; the body core temperature is controlled to $37^{\circ} \mathrm{C}$. So, the Dirichlet's inner boundary condition during the activity period is taken as

$$
T\left(y_{3}\right)=T_{b}=37^{\circ} \mathrm{C},
$$

where $T_{b}$ is the body core temperature and $y_{3}$ is the total thickness of skin.

Using Euler-Lagrange formula, the variational integral form of equations (6) and (7) is given by

$$
\begin{aligned}
I[T(x, t)]= & \frac{1}{2} \int_{\Omega}\left[K\left(\frac{\mathrm{d} T}{\mathrm{~d} x}\right)^{2}+M\left(T_{A}-T\right)^{2}-2 Q_{m}(t) T+\rho c \frac{\mathrm{d} T^{2}}{\mathrm{~d} t}\right] \mathrm{d} x \\
& +\frac{1}{2} h\left(T_{0}-T_{\infty}\right)^{2}+L E_{\mathrm{st}} T_{0},
\end{aligned}
$$

where $\Omega=$ skin layered domain.

In this model, the physical and physiological parameters depending on the epidermis, dermis, and subcutaneous tissue are given in Table 3 .
Let $I_{k}$, for $k=1,2,3$, be the integral solutions of three layers, epidermis, dermis, and subcutaneous tissue, respectively, with $I=\sum_{k=1}^{3} I_{k}$. Solving the integrals $I_{1}, I_{2}$, and $I_{3}$ with parameters as mentioned in Table 3 , we obtain the 


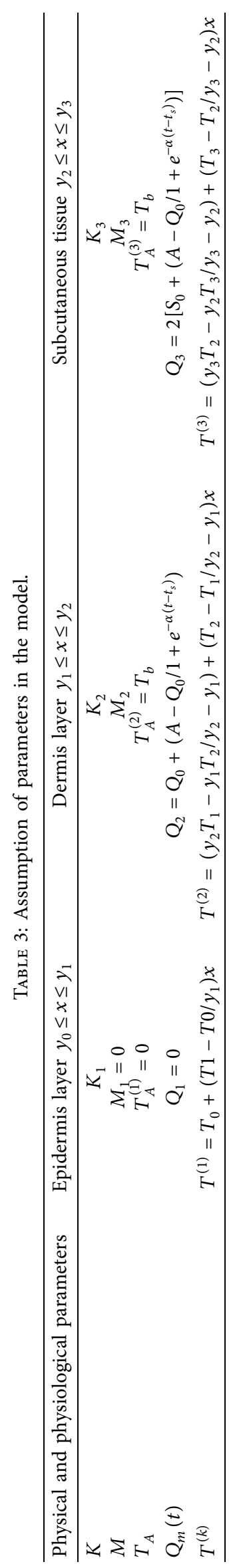


solution $I_{1}, I_{2}$, and $I_{3}$ as functions of nodal values $T_{0}, T_{1}, T_{2}$, as given as follows:

$$
\begin{aligned}
& I_{1}=A_{1}+B_{1} T_{0}+D_{1} T_{o}^{2}+E_{1} T_{1}^{2}+F_{1} T_{0} T_{1}+\alpha_{1} \frac{\mathrm{d}}{\mathrm{d} t}\left(T_{0}^{2}+T_{1}^{2}+T_{0} T_{1}\right), \\
& I_{2}=A_{2}+B_{2} T_{1}+C_{2} T_{2}+D_{2} T_{1}^{2}+E_{2} T_{2}^{2}+F_{2} T_{1} T_{2}+\alpha_{2} \frac{\mathrm{d}}{\mathrm{d} t}\left(T_{1}^{2}+T_{2}^{2}+T_{1} T_{2}\right), \\
& I_{3}=A_{3}+B_{3} T_{2}+C_{3} T_{3}+D_{3} T_{2}^{2}+E_{3} T_{3}^{2}+F_{3} T_{2} T_{3}+\alpha_{3} \frac{\mathrm{d}}{\mathrm{d} t}\left(T_{2}^{2}+T_{3}^{2}+T_{2} T_{3}\right),
\end{aligned}
$$

where $A_{i}, B_{i}, D_{i}, E_{i}, F_{i}$, and $C_{j}$ with $1 \leq i \leq 3$ and $2 \leq j \leq 3$ are all constants whose values depend on physical and physiological parameters of dermal parts as given in Table 4. To obtain the result, differentiate $I_{1}, I_{2}$, and $I_{3}$ with respect to $T_{0}, T_{1}$, and $T_{2}$ and set $\left(\mathrm{d} I / \mathrm{d} T_{k}\right)=0$, for $k=0,1,2$. On simplification, we obtain system of equations in matrix form:

$$
C T+R \dot{T}=U
$$

where

$$
\begin{aligned}
& C=\left(\begin{array}{ccc}
2 D_{1} & F_{1} & 0 \\
F_{1} & 2\left(D_{2}+E_{1}\right) & F_{2} \\
0 & F_{2} & 2\left(D_{3}+E_{2}\right)
\end{array}\right) \text {, } \\
& R=\left(\begin{array}{ccc}
2 \alpha_{1} & \alpha_{1} & 0 \\
\alpha_{1} & 2\left(\alpha_{1}+\alpha_{2}\right) & \alpha_{2} \\
0 & \alpha_{2} & 2\left(\alpha_{2}+\alpha_{3}\right)
\end{array}\right) \text {, } \\
& T=\left(\begin{array}{c}
T_{0} \\
T_{1} \\
T_{2}
\end{array}\right) \\
& \dot{T}=\left(\begin{array}{c}
\frac{\mathrm{d} T_{0}}{\mathrm{~d} t} \\
\frac{\mathrm{d} T_{1}}{\mathrm{~d} t} \\
\frac{\mathrm{d} T_{2}}{\mathrm{~d} t}
\end{array}\right), \\
& U=\left(\begin{array}{c}
-B_{1} \\
-B_{2} \\
-C_{2}-B_{3}-F_{3} T_{3}
\end{array}\right) .
\end{aligned}
$$

\section{Numerical Results and Discussion}

During physical activities, walking, cleaning, and cooking, the doorsill values of metabolic rates are $3889.43 \mathrm{w} / \mathrm{m}^{3}$, $3266.67 \mathrm{w} / \mathrm{m}^{3}$, and $2212.16 \mathrm{w} / \mathrm{m}^{3}$, respectively. In this model, two sets of skin layers thickness set I and set II are taken as in Table 5 and sweat evaporation rates for different ambient temperatures during various activities for the skin set I and set II are presented in Tables 6 and 7, respectively. The values of physical and physiological parameters used for numerical simulation are taken as given in Table 4 .

Under normal conditions, the temperature decreases from the body core towards the skin surface. So we consider $T_{0}, T_{1}$, and $T_{2}$ to be in linear order towards body core at $t=0$. Thus we assume the equation

$$
T(x, 0)=T_{0}+\kappa x
$$

where $\kappa$ is an adoption constant in equation (13) and is calculated by using $T_{b}=37^{\circ} \mathrm{C}$ at $x=y_{3}$. For the initial value of the interface temperatures, we consider the skin surface temperature as $22.87^{\circ} \mathrm{C}$. Equation (11) is solved by using the Crank-Nicolson method. The Crank-Nicolson method provides

$$
\left(R+\frac{\Delta t}{2} C\right) T^{(i+1)}=\left(R-\frac{\Delta t}{2} C\right) T^{(i)}+\Delta t U .
$$

Here, $\Delta t$ is the time interval and $T^{(0)}$ is the initial nodal temperature in $3 \times 1$ matrix form. For the steady case of the model, we obtain the following matrix form of the system of algebraic equation:

$$
C T=U
$$

5.1. Steady State Results. The steady-state temperature results of the natural skin layers epidermis, dermis, and subcutaneous tissue (SST) at the various ambient temperatures $T_{\infty}=15^{\circ} \mathrm{C}, 25^{\circ} \mathrm{C}, 35^{\circ} \mathrm{C}$, and $45^{\circ} \mathrm{C}$, during cooking, cleaning, and walking, are presented through the graph in Figures $4-8$ and Tables 8 and 9 for skin sets I and II by solving the system of equation (15).

Figures 4(a)-4(c) represent the steady state temperatures of epidermis, dermis, and subcutaneous tissue at $T_{\infty}=15^{\circ} \mathrm{C}$, $25^{\circ} \mathrm{C}, 35^{\circ} \mathrm{C}$, and $45^{\circ} \mathrm{C}$ during cooking, cleaning, and walking, 
TABLe 4: Parameter values used in model $[1,14]$.

\begin{tabular}{lcccccccc}
\hline Parameter & $L$ & $K_{1}$ & $K_{2}$ & $K_{3}$ & $h$ & $M_{2}=M_{3}$ & $\rho_{1}=\rho_{2}=\rho_{3}$ & $c_{1}=c_{2}=c_{3}$ \\
\hline Value & 2420220 & 0.209 & 0.314 & 0.418 & 6.27 & 1254 & 1050 & 3469.4 \\
Unit & $\mathrm{J} / \mathrm{kg}$ & $\mathrm{w} / \mathrm{m}^{\circ} \mathrm{C}$ & $\mathrm{w} / \mathrm{m}^{\circ} \mathrm{C}$ & $\mathrm{w} / \mathrm{m}^{\circ} \mathrm{C}$ & $\mathrm{w} / \mathrm{m}^{2^{\circ} \mathrm{C}}$ & $\mathrm{w} / \mathrm{m}^{3^{\circ} \mathrm{C}}$ & $\mathrm{kg} / \mathrm{m}^{3}$ & $\mathrm{~J} / \mathrm{kg}^{\circ} \mathrm{C}$ \\
\hline
\end{tabular}

TABLe 5: The thickness of skin layers set I and set II [5].

\begin{tabular}{lccc}
\hline $\begin{array}{l}\text { Skin } \\
\text { layers }\end{array}$ & $\begin{array}{c}\text { Epidermis layer thickness }\left(y_{1}\right) \\
\text { (meters) }\end{array}$ & $\begin{array}{c}\text { Dermis layer thickness }\left(y_{2}-y_{1}\right) \\
\text { (meters) }\end{array}$ & $\begin{array}{c}\text { Subcutaneous tissue thickness }\left(y_{3}-y_{2}\right) \\
(\text { meters })\end{array}$ \\
\hline Set I & 0.001 & 0.0035 & 0.005 \\
Set II & 0.001 & 0.004 & 0.009 \\
\hline
\end{tabular}

TABle 6: Sweat evaporation rate at different ambient temperatures during cooking, cleaning, and walking for skin set I.

\begin{tabular}{lccc}
\hline $\begin{array}{l}\text { Ambient } \\
\text { temperature }\end{array}$ & $\begin{array}{c}\text { Sweat evaporation rate during } \\
\text { cooking }\left(\mathrm{kg} / \mathrm{m}^{2} \cdot \mathrm{s}\right)\end{array}$ & $\begin{array}{c}\text { Sweat evaporation rate during } \\
\text { cleaning }\left(\mathrm{kg} / \mathrm{m}^{2} \cdot \mathrm{s}\right)\end{array}$ & $\begin{array}{c}\text { Sweat evaporation rate during } \\
\text { walking }\left(\mathrm{kg} / \mathrm{m}^{2} \cdot \mathrm{s}\right)\end{array}$ \\
\hline $15^{\circ} \mathrm{C}$ & $17.253 \times 10^{-6}$ & $17.491 \times 10^{-6}$ & $17.627 \times 10^{-6}$ \\
$25^{\circ} \mathrm{C}$ & $25.037 \times 10^{-6}$ & $25.274 \times 10^{-6}$ & $25.410 \times 10^{-6}$ \\
$35^{\circ} \mathrm{C}$ & $32.821 \times 10^{-6}$ & $33.050 \times 10^{-6}$ & $33.190 \times 10^{-6}$ \\
$45^{\circ} \mathrm{C}$ & $40.597 \times 10^{-6}$ & $40.834 \times 10^{-6}$ & $40.978 \times 10^{-6}$ \\
\hline
\end{tabular}

TABLE 7: Sweat evaporation rate at different ambient temperatures during cooking, cleaning, and walking for skin set II.

\begin{tabular}{lccc}
\hline $\begin{array}{l}\text { Ambient } \\
\text { temperature }\end{array}$ & $\begin{array}{c}\text { Sweat evaporation rate during } \\
\text { cooking }\left(\mathrm{kg} / \mathrm{m}^{2} \cdot \mathrm{s}\right)\end{array}$ & $\begin{array}{c}\text { Sweat evaporation rate during } \\
\text { cleaning }\left(\mathrm{kg} / \mathrm{m}^{2} \cdot \mathrm{s}\right)\end{array}$ & $\begin{array}{c}\text { Sweat evaporation rate during } \\
\text { walking }\left(\mathrm{kg} / \mathrm{m}^{2} \cdot \mathrm{s}\right)\end{array}$ \\
\hline $15^{\circ} \mathrm{C}$ & $11.104 \times 10^{-6}$ & $12.307 \times 10^{-6}$ & $13.019 \times 10^{-6}$ \\
$25^{\circ} \mathrm{C}$ & $22.589 \times 10^{-6}$ & $23.784 \times 10^{-6}$ & $24.495 \times 10^{-6}$ \\
$35^{\circ} \mathrm{C}$ & $34.066 \times 10^{-6}$ & $35.269 \times 10^{-6}$ & $35.972 \times 10^{-6}$ \\
$45^{\circ} \mathrm{C}$ & $45.543 \times 10^{-6}$ & $46.746 \times 10^{-6}$ & $47.449 \times 10^{-6}$ \\
\hline
\end{tabular}

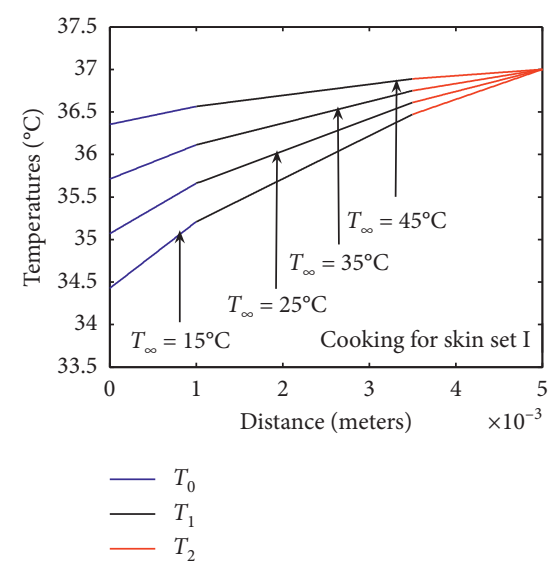

(a)

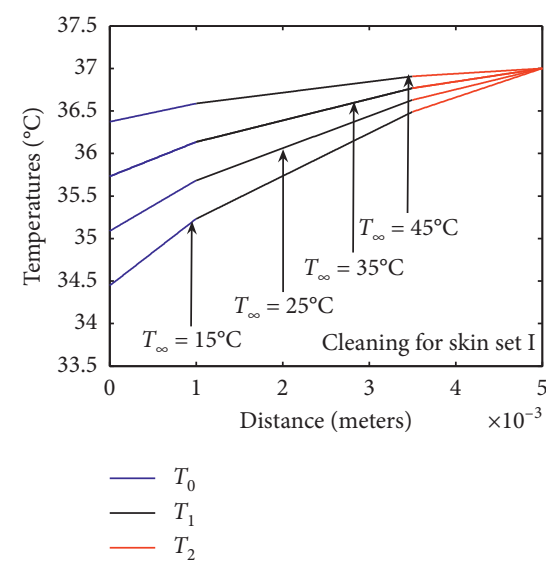

(b)

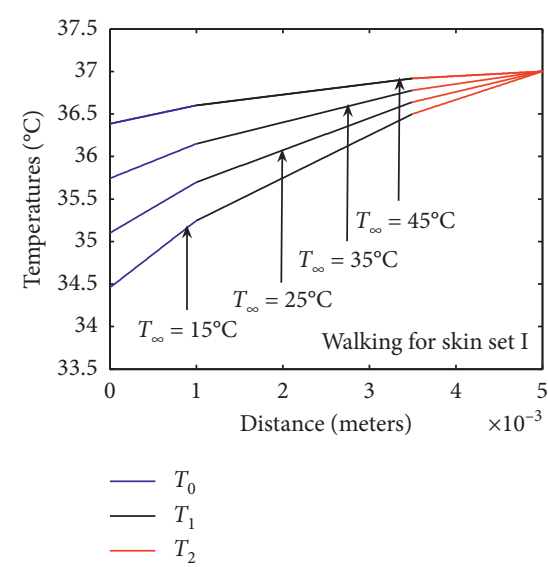

(c)

Figure 4: Estimation of epidermis dermis and subcutaneous tissue temperature for various evaporation rates at $T_{\infty}=15^{\circ} \mathrm{C}, 25^{\circ} \mathrm{C}, 35^{\circ} \mathrm{C}$, and $45^{\circ} \mathrm{C}$ during cooking, cleaning, and walking for skin set I. (a) Cooking. (b) Cleaning. (c) Walking.

respectively, for skin set I. Its numerical results are presented in Table 8. Figures 5(a)-5(c) indicate the interface temperatures of epidermis, dermis, and subcutaneous tissue at $T_{\infty}=15^{\circ} \mathrm{C}, 25^{\circ} \mathrm{C}, 35^{\circ} \mathrm{C}$, and $45^{\circ} \mathrm{C}$ during cooking, cleaning, and walking, respectively, for skin set II and obtained values are shown in Table 9.

Both results exhibit that each steady state temperature of epidermis, dermis, and subcutaneous tissue during walking 


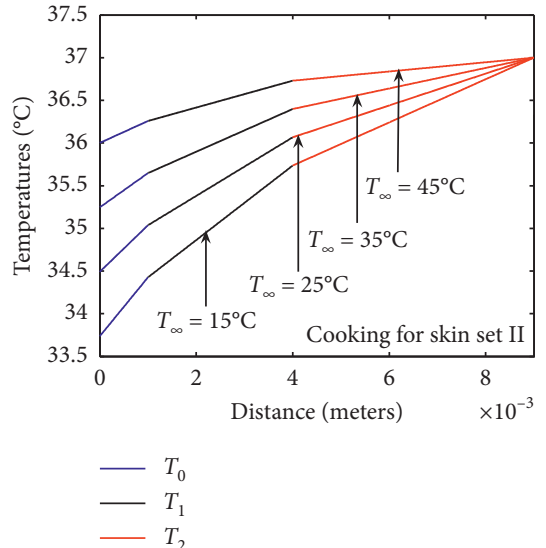

(a)

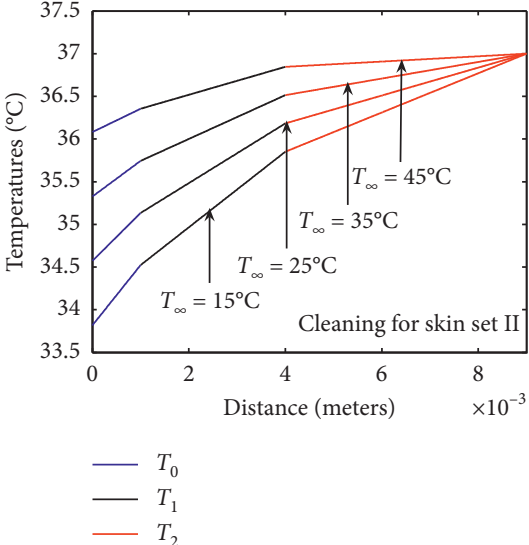

(b)

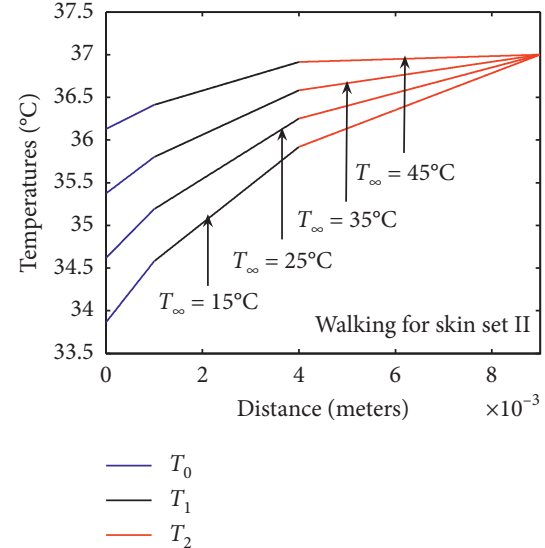

(c)

Figure 5: Observation epidermis, dermis and subcutaneous interface temperature for various evaporation rates at $T_{\infty}=15^{\circ} \mathrm{C}, 25^{\circ} \mathrm{C}, 35^{\circ} \mathrm{C}$, and $45^{\circ} \mathrm{C}$ during cooking, cleaning, and walking for skin set II. (a) Cooking. (b) Cleaning. (c) Walking.

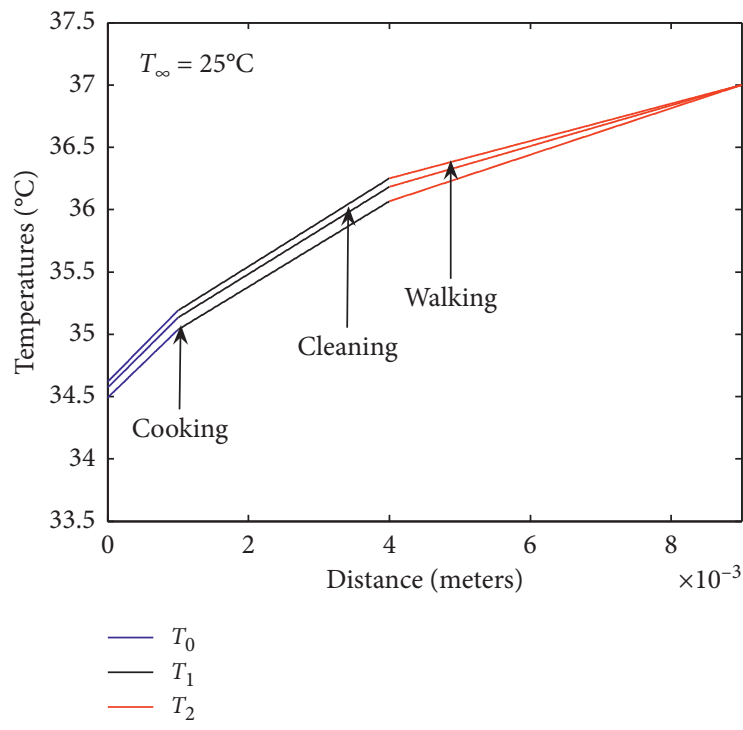

(a)

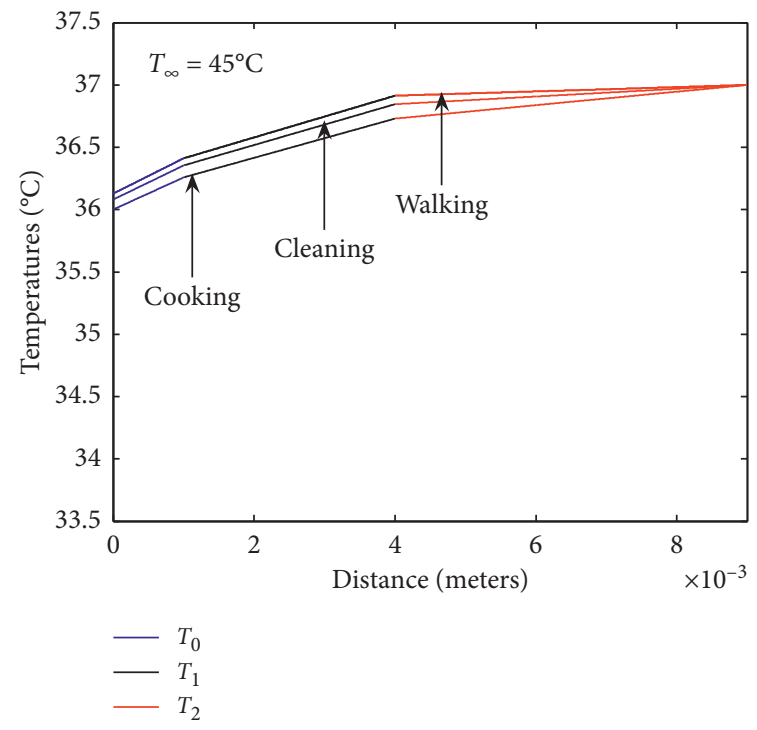

(b)

Figure 6: Comparison of epidermis, dermis and subcutaneous tissue temperatures for skin set II, during cooking, cleaning, and waking at (a) $T_{\infty}=25^{\circ} \mathrm{C}$ and (b) $T_{\infty}=45^{\circ} \mathrm{C}$.

is more than cooking and cleaning, because during walking the body consumes more oxygen and produces more metabolic heat energy as compared to cleaning and cooking at each ambient temperature. Furthermore, the steady state skin layers temperature at high ambient temperature is more than at low ambient temperature during each activity. These are due to the fact that at high ambient temperature the blood vessels dilate, and the sweat glands begin to secrete more sweat than in low ambient temperature during each activity.

The steady state interface temperatures of the SST region during cooking, cleaning, and walking at (a) $T_{\infty}=25^{\circ} \mathrm{C}$ and (b) $T_{\infty}=45^{\circ} \mathrm{C}$ are compared in Figures 6(a) and 6(b), respectively, for skin set II. The obtained numerical results are presented in Table 9. The numerical results analyzed that steady state temperatures of epidermis, dermis, and subcutaneous tissue are slightly higher by $0.13^{\circ} \mathrm{C}, 0.15^{\circ} \mathrm{C}$, and $0.18^{\circ} \mathrm{C}$, during walking than cooking in both ambient temperatures $25^{\circ} \mathrm{C}$ and $45^{\circ} \mathrm{C}$. The results exhibit that during walking, the body generates more heat energy as compared to cooking and some surplus heat energy losses from the body through the sweat in the form of water, and the body keeps in thermoregulation.

Figures 7(a) and 7(b) show the comparison of steady state interface temperatures of the epidermis, dermis, and subcutaneous tissue between the skin set I and skin set II, during cleaning at $T_{\infty}=15^{\circ} \mathrm{C}$ and the $35^{\circ} \mathrm{C}$ and walking at $T_{\infty}=25^{\circ} \mathrm{C}$ and $45^{\circ} \mathrm{C}$, respectively. These results demonstrate that epidermis layer temperature is increased by $0.62^{\circ} \mathrm{C}$, the dermis layer temperature is increased by $0.71^{\circ} \mathrm{C}$, 


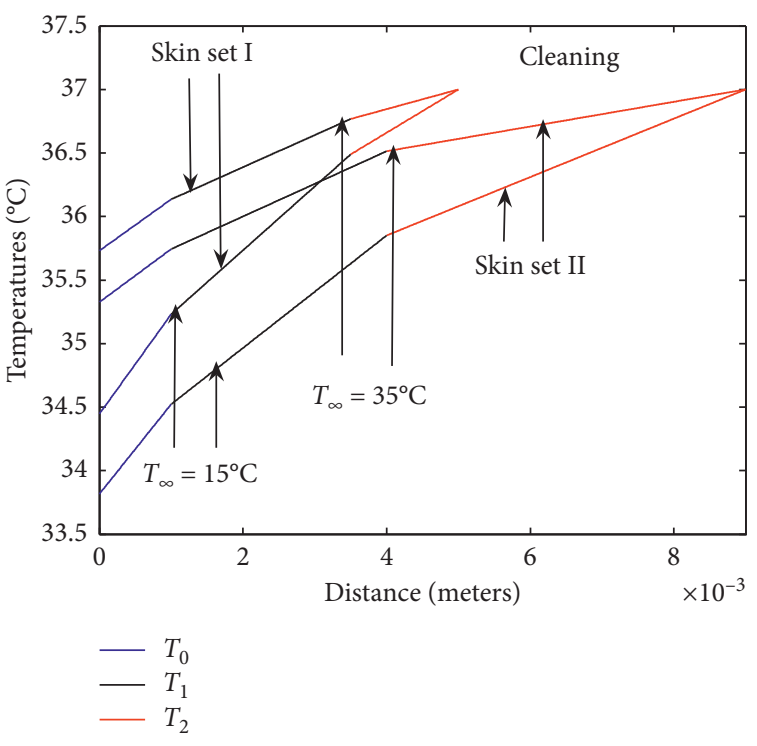

(a)

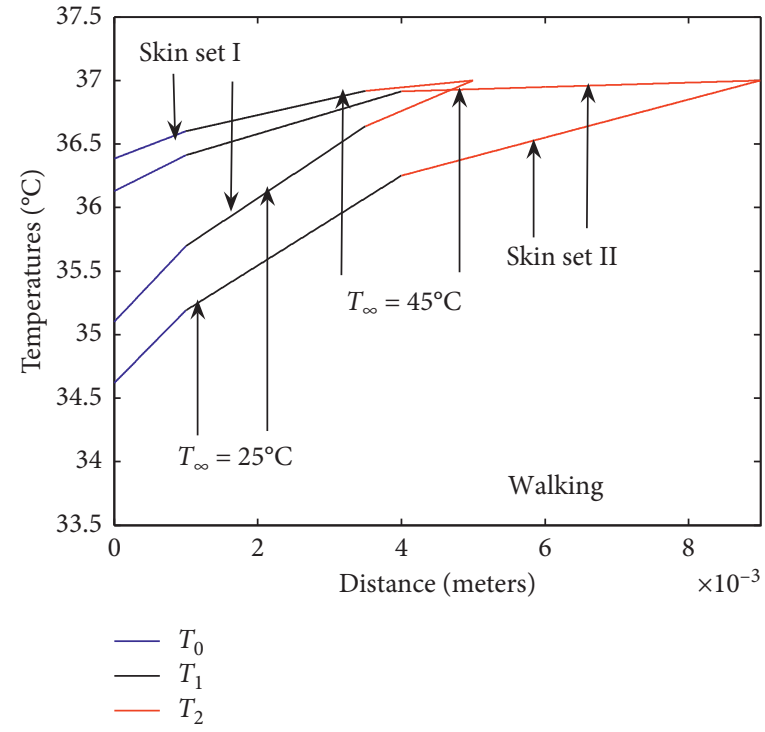

(b)

Figure 7: Comparison of epidermis, dermis, and subcutaneous tissue temperatures in skin sets I and II at (a) $T_{\infty}=15^{\circ} \mathrm{C}$ and $35^{\circ} \mathrm{C}$ during cleaning (b) $T_{\infty}=25^{\circ} \mathrm{C}$ and $45^{\circ} \mathrm{C}$ during walking.

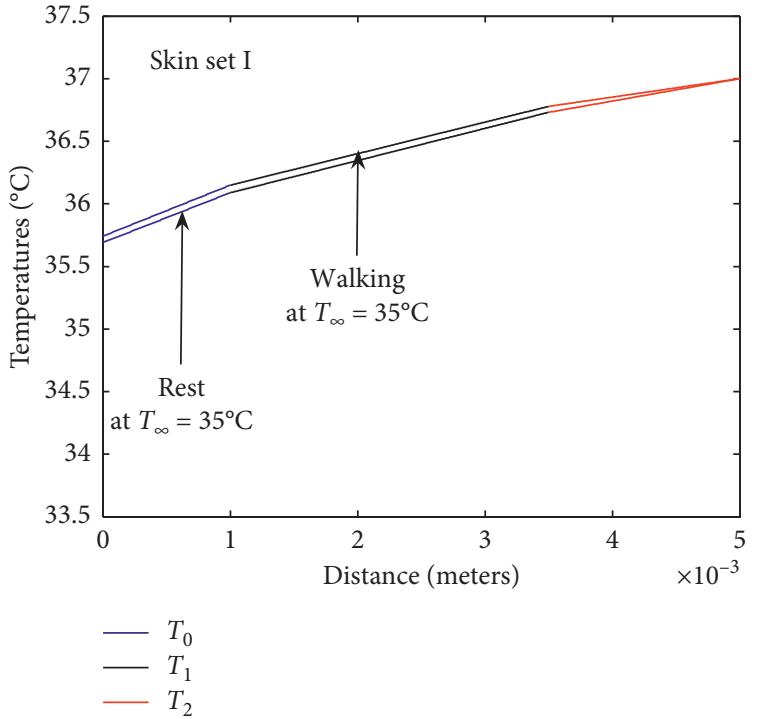

(a)

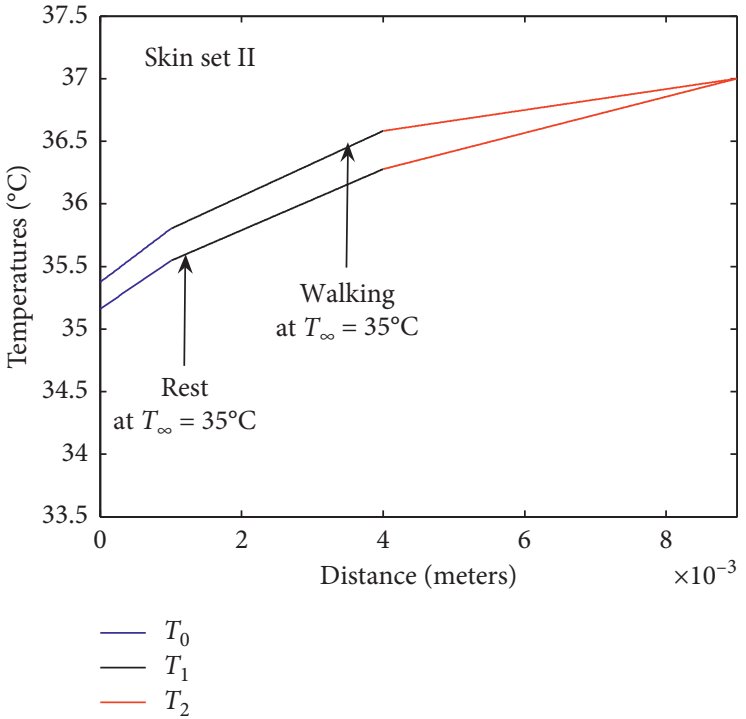

(b)

Figure 8: Comparison of epidermis, dermis, and subcutaneous tissue temperatures at rest and during walking at $T_{\infty}=35^{\circ} \mathrm{C}$ in skin (a) set I and (b) set II.

and subcutaneous tissue temperature is increased by $0.64^{\circ} \mathrm{C}$ in skin set I than skin set II at $T_{\infty}=15^{\circ} \mathrm{C}$. At $T_{\infty}=35^{\circ} \mathrm{C}$ also the steady state temperatures of epidermis, dermis, and subcutaneous tissue are, respectively, higher by $0.40^{\circ} \mathrm{C}$, $0.40^{\circ} \mathrm{C}$, and $0.26^{\circ} \mathrm{C}$ in skin set I than the skin set II during cleaning.

During walking, the steady state interface temperatures of epidermis, dermis, and subcutaneous tissue are, respectively, increased by $0.48^{\circ} \mathrm{C}, 0.51^{\circ} \mathrm{C}$, and $0.39^{\circ} \mathrm{C}$, at
$T_{\infty}=25^{\circ} \mathrm{C}$ and $0.25^{\circ} \mathrm{C}, 0.19^{\circ} \mathrm{C}$, and $0.01^{\circ} \mathrm{C}$, at $T_{\infty}=45^{\circ} \mathrm{C}$ in skin set I than skin set II. Both results predict that the thickness of skin layers plays an important role to maintains body temperature. Figure 8 reveals that each steady state temperature of epidermis, dermis, and subcutaneous tissue during walking is raised by $0.21^{\circ} \mathrm{C}$, $0.25^{\circ} \mathrm{C}$, and $0.30^{\circ} \mathrm{C}$ from at rest with temperatures $35.16^{\circ} \mathrm{C}$, $35.55^{\circ} \mathrm{C}$, and $36.00^{\circ} \mathrm{C}$ due to increasing the rate of oxygen consumption in the blood. 
TABLE 8: Estimation of nodal temperature in dermal layers at various sweat evaporation rates at rest and during cooking, cleaning, and walking for skin set I.

\begin{tabular}{lcccc}
\hline Position & $T_{\infty}\left({ }^{\circ} \mathrm{C}\right)$ & $T_{0}\left({ }^{\circ} \mathrm{C}\right)$ & $T_{1}\left({ }^{\circ} \mathrm{C}\right)$ \\
\hline At rest & 15 & 34.41 & 35.18 & $T_{2}\left({ }^{\circ} \mathrm{C}\right)$ \\
During cooking & 15 & 34.43 & 35.21 & 36.45 \\
During cleaning & 15 & 34.44 & 35.24 & 36.47 \\
During walking & 15 & 34.46 & 35.64 & 36.49 \\
At rest & 25 & 35.05 & 35.66 & 36.50 \\
During cooking & 25 & 35.07 & 35.68 & 36.61 \\
During cleaning & 25 & 35.09 & 36.09 & 36.63 \\
During walking & 25 & 35.10 & 36.11 & 36.64 \\
At rest & 35 & 35.69 & 36.14 \\
During cooking & 35 & 35.71 & 36.15 \\
During cleaning & 35 & 35.73 & 36.54 \\
During walking & 35 & 36.74 & 36.56 \\
At rest & 45 & 36.35 & 36.59 \\
During cooking & 45 & 36.37 & 36.60 \\
During cleaning & 45 & 36.38 & 36.73 \\
During walking & 45 & & 36.78 \\
\hline
\end{tabular}

TABLE 9: Estimation of nodal temperature in dermal layers at various sweat evaporation rates at rest and during cooking, cleaning, and walking for skin set II.

\begin{tabular}{lcccc}
\hline Position & $T_{\infty}\left({ }^{\circ} \mathrm{C}\right)$ & $T_{0}\left({ }^{\circ} \mathrm{C}\right)$ & $T_{1}\left({ }^{\circ} \mathrm{C}\right)$ & 34.42 \\
\hline At rest & 15 & 33.65 & 34.43 & 34.52 \\
During cooking & 15 & 33.74 & 34.58 \\
During cleaning & 15 & 33.82 & 34.93 & 35.74 \\
During walking & 15 & 33.86 & 35.04 \\
At rest & 25 & 34.41 & 35.13 \\
During cooking & 25 & 34.49 & 35.19 \\
During cleaning & 25 & 34.57 & 35.55 \\
During walking & 25 & 34.62 & 35.65 \\
At rest & 35 & 35.16 & 35.74 \\
During cooking & 35 & 35.24 & 35.80 \\
During cleaning & 35 & 35.33 & 36.41 \\
During walking & 35 & 35.37 & 36.26 \\
At rest & 45 & 36.23 & 36.95 \\
During cooking & 45 & 36.00 & 36.07 \\
During cleaning & 45 & 36.08 & 36.41 \\
During walking & 45 & 36.13 & 36.18 \\
\hline
\end{tabular}

5.2. Unsteady State Results. The numerical calculation for the unsteady state temperatures solution $T_{i}(i=0,1,2)$ is carried out by solving the system of equation (11).

The temperature $T_{2}$ shows the highest and reaches the steady state temperature later at $T_{\infty}=45^{\circ} \mathrm{C}$ as compared to the other ambient temperatures due to the metabolic effects shown in Figure 9 during cleaning; even the sweating rate is higher at a high ambient temperature.

Figure 10 shows the unsteady state temperatures $T_{0}$ and $T_{1}$ reach steady state temperature with temperature gradient $0.21^{\circ} \mathrm{C}$ at $T_{\infty}=45^{\circ} \mathrm{C}$ and $0.78^{\circ} \mathrm{C}$ at $T_{\infty}=15^{\circ}$ during cooking for skin set $\mathrm{I}$. These results show that the high ambient temperature affects more the epidermis layer's temperature than the dermis layer's temperature due to the epidermis layer being closer to the environment. Furthermore, in a high ambient temperature, the dermis layer's temperature is closer to the epidermis layer's temperature due to the cause of sweat evaporation and is nearer to the body core.

The graph of Figure 11 shows that the unsteady state temperatures $T_{1}$ almost coincide with each other during walking, cleaning, and cooking at the same ambient temperature, because during walking the body produces more metabolic heat energy and releases more heat in the form of sweat than cooking and cleaning. The metabolic energy affects very little body temperature variation.

On comparing $T_{0}$ between skin set I and set II in Figure 12, $T_{0}$ is higher and reach steady earlier for skin set I as a comparison to the skin set II. These are due to the cause of lean muscle mass considering the less thickness of skin set I than skin set II.

The unsteady state temperature $T_{2}$ decreases fast initially and then immediately increases as shown in Figure 13 


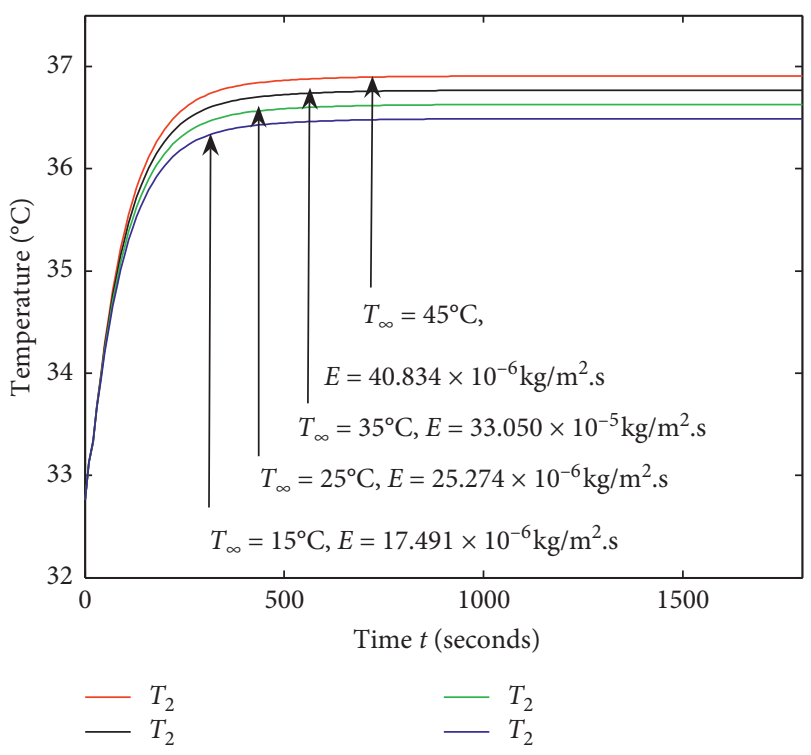

Figure 9: Comparison of the unsteady state temperatures $T_{2}$ during cleaning at $T_{\infty}=15^{\circ} \mathrm{C}, 25^{\circ} \mathrm{C}, 35^{\circ} \mathrm{C}$, and $45^{\circ} \mathrm{C}$ for skin set $\mathrm{I}$.

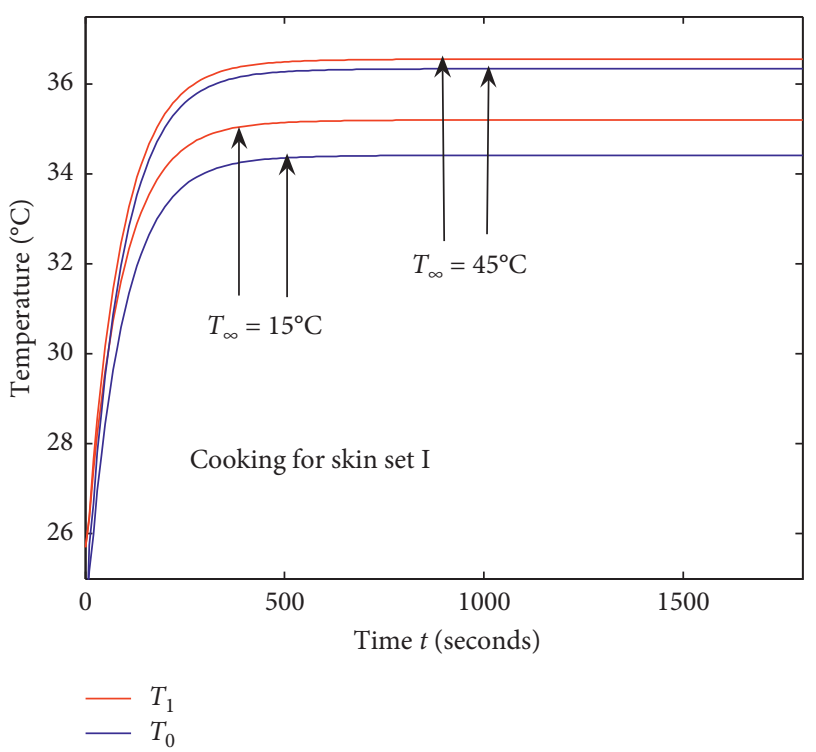

Figure 10: Comparison of the unsteady state temperatures $T_{0}, T_{1}$, and $T_{2}$ during cooking at $T_{\infty}=15^{\circ} \mathrm{C}$ and $45^{\circ} \mathrm{C}$ for skin set $\mathrm{I}$.

during walking. The figure reveals that $T_{1}$ gradually increases from the beginning, reaching a steady state temperature. These results exhibit that the steady state temperature $T_{2}$ is higher by $0.78^{\circ} \mathrm{C}$ than the steady state temperature $T_{1}$. Furthermore, the unsteady state temperature $T_{2}$ approaches steady temperature faster than $T_{1}$, because in subcutaneous tissue the metabolic rate increases due to an increase in the lean muscle mass and loss the adipose fat tissue during the activity.

Figures 14 and 15 indicate the unsteady state temperatures $T_{0}$ and $T_{2}$ approach the steady state temperatures

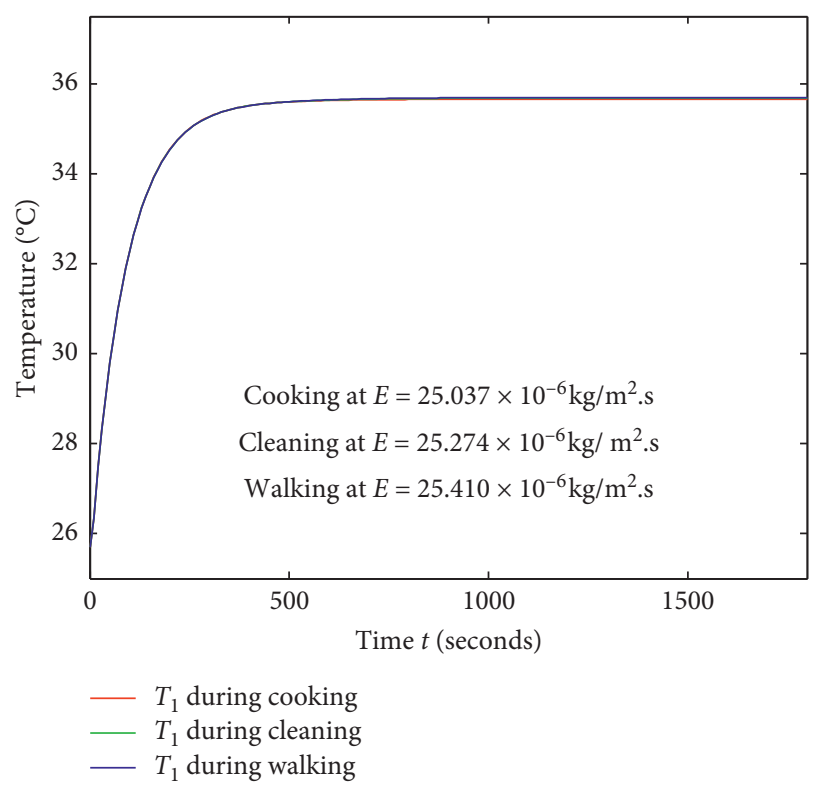

FIgURE 11: Comparison of unsteady state temperatures $T_{1}$ during cooking, cleaning, and walking at $T_{\infty}=25^{\circ} \mathrm{C}$ for skin set I.

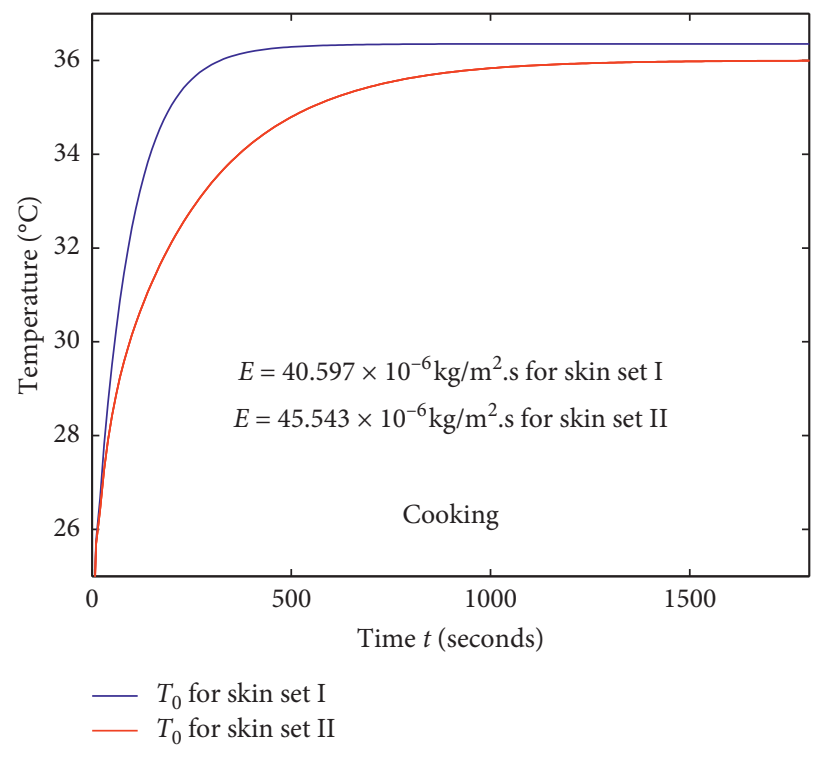

Figure 12: Comparison of the unsteady state temperatures $T_{0}$ during cooking at $T_{\infty}=45^{\circ} \mathrm{C}$ between skin set I and skin set II.

after the periods of approximately 990 seconds and 560 seconds, respectively, for skin set I and approximately after the periods of 1640 seconds and 1390 seconds, respectively, for skin set II. Both figures have shown that the unsteady state temperature $T_{2}$ reaches faster the steady state temperature as compared to $T_{0}$. The results also exhibit that the unsteady state temperatures of skin set I reach earlier the steady state temperatures than the skin set II due to the thermal law of cooling. 


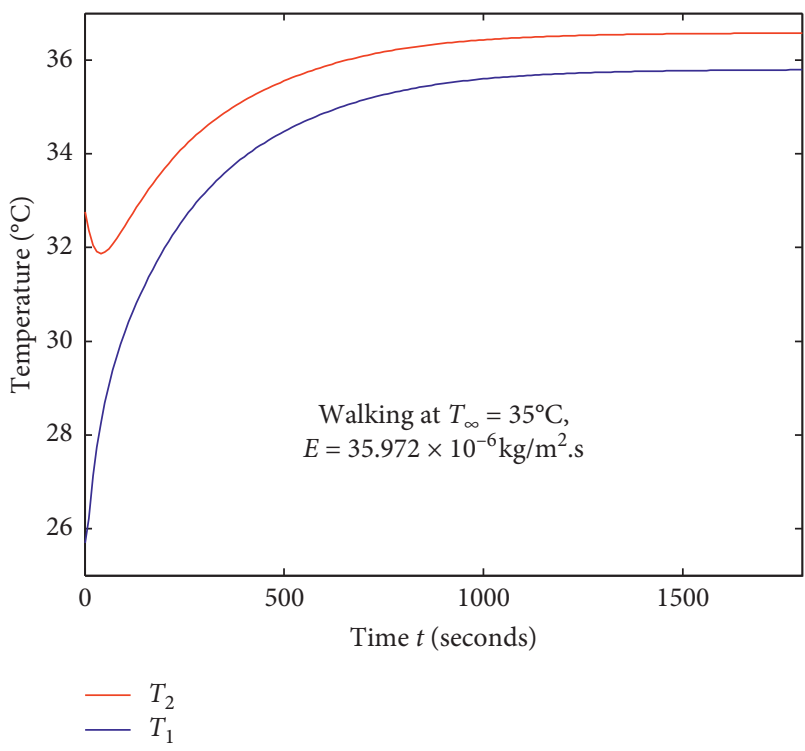

FIgURE 13: Comparison of the unsteady state temperatures $T_{1}$ and $T_{2}$ during walking at $T_{\infty}=35^{\circ} \mathrm{C}$ for skin set II.

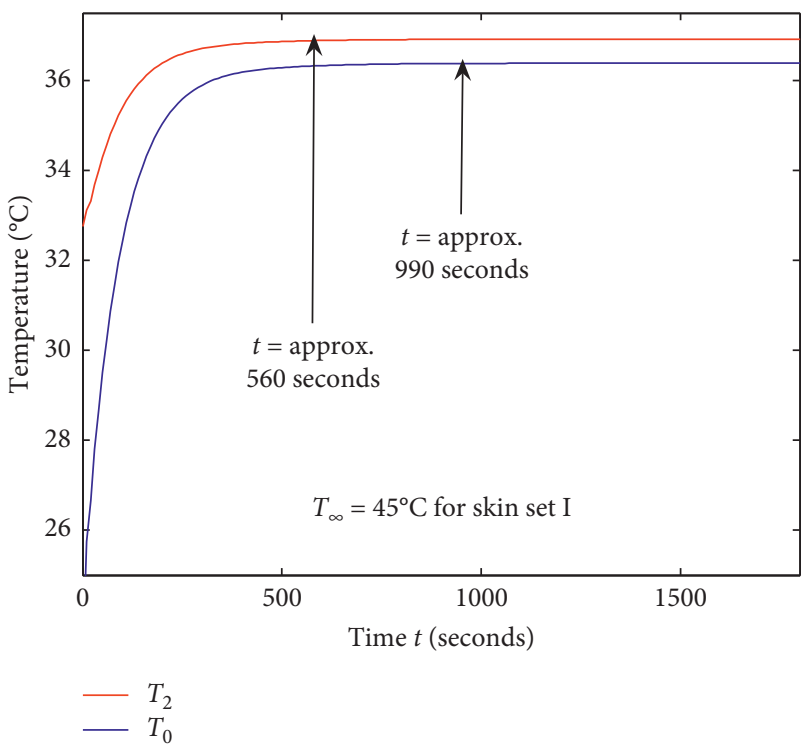

Figure 14: Time estimation from unsteady state to the steady state temperatures for the epidermis and subcutaneous nodal during walking at $T_{\infty}=45^{\circ} \mathrm{C}$ for skin set $\mathrm{I}$.

All the figures of the unsteady state nodal temperature of each layer demonstrate that the temperature of each layer rises at the beginning of each activity and quickly reaches steady state temperatures by releasing sweat. These scores execute that sweat evaporation plays a crucial role in thermoregulation in the human body.

The above results also reveal that the steady state temperatures $T_{i},(i=0,1,2)$ are almost similar in both steady and unsteady cases during cooking, cleaning, and walking, at the same ambient temperature and same skin thickness.

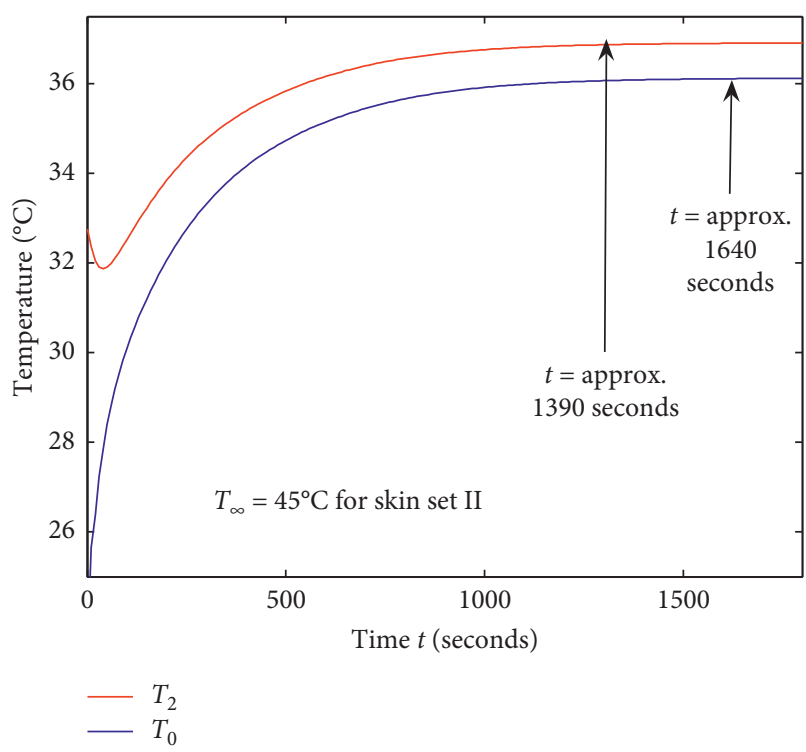

Figure 15: Time estimation from unsteady state to the steady state temperatures for the epidermis and subcutaneous nodal during walking at $T_{\infty}=45^{\circ} \mathrm{C}$ for skin set II.

\section{Conclusion}

The results in the model show that, on increasing the metabolic energy, steady state interface temperature of skin layers increases. The steady state temperature of each skin layer also rises on raising the ambient temperature, because of the circulating blood near the skin surface heat in both situations. But due to the doorsill value of body core temperature, the body produces necessary sweat, controls the body temperature, and keeps the body normal. It reveals that sweat evaporation plays the leading role in protecting the body from hyperthermia disorder at high ambient temperature.

In low ambient temperature $\left(15^{\circ} \mathrm{C}\right.$ and $\left.25^{\circ} \mathrm{C}\right)$, the thinner skin layer releases more sweat than the thicker skin layer due to a high metabolic rate that occurs in a cold environment in thin skin layers. But at high ambient temperatures $\left(35^{\circ} \mathrm{C}\right.$ and $45^{\circ} \mathrm{C}$ ), the thicker skin layer produces more sweat than the thinner skin layer due to more blood flow rate in a hot environment in the thicker skin layer. The results predict that the thickness of the skin layers also plays a vital role to control body temperature.

Previously, the researchers developed models in the temperature distribution in the human dermal part that has not determined the metabolic rate during the activities period. So this model is prepared for the realistic temperature distribution in dermal parts of the human body due to the effect of metabolic rate and ambient temperature controlled by sweat evaporation during activities. So, this paper will be helpful to maintain the physical structure for younger elderly and old elderly from sarcopenia. It also helps to develop the models regarding moderate- and high-intensity exercises as wrestling players, mountain climbers, cyclists, typist, etc., based on their physical and physiological characters. 


\section{Data Availability}

The data used to support the findings of this study are included within the article.

\section{Conflicts of Interest}

The authors declare that they have no conflicts of interest.

\section{References}

[1] D. B. Gurung and S. Acharya, "Sweating effect on males and females body temperature variation," Journal of Computational and Applied Mathematics, vol. 7, no. 3, pp. 1-11, 2018.

[2] K. Nagashima, K. Tokizawa, Y. Uchida, M. Nakamura-Matsuda, and C.-H. Lin, "Exercise and thermoregulation," The Journal of Physical Fitness and Sports Medicine, vol. 1, no. 1, pp. 73-82, 2012.

[3] M. N. Sawka, Nutritional Needs in Hot Environments, pp. 3-44, The National Academic of Sciences, Engineering and Medicine, National Academy Press, Washington, DC, USA, 1993.

[4] E. Arens and H. Zhang, "The skin's role in human thermoregulation and comfort," Thermal and Moisture Transport in Fibrous Materials, Center for the Built Environment, Berkeley, CA, USA, pp. 560-602, 2006.

[5] D. B. Gurung, "Mathematical study of abnormal thermoregulation in human dermal part" Ph.D. thesis, Kathmandu University, Dhulikhel, Nepal, 2007.

[6] M. Díaz and D. E. Becker, "Thermoregulation: physiological and clinical considerations during sedation and general anesthesia," Anesthesia Progress, vol. 57, no. 1, pp. 25-33, 2010.

[7] J. V. G. A. Durnin, "Energy metabolism in the elderly," Nutrition of the Elderly, vol. 29, pp. 51-63, Raven Press, NewYork, NY, USA, 1992.

[8] D. C. Agrawal, "Work and heat expenditure during swimming," Physics Education, vol. 34, no. 4, pp. 220-225, 1999.

[9] A. D. A. Fernandes, P. R. D. S. Amorim, C. J. Brito et al., "Measuring skin temperature before, during and after exercise: a comparison of thermocouples and infrared thermography," Physiological Measurement, vol. 35, no. 2, pp. 189-203, 2014.

[10] H. H. Pennes', "Analysis of tissue and arterial blood temperature in resting human forearm," Journal of Applied Physiology, vol. 1, no. 2, pp. 93-122, 1998.

[11] S. Veselá, B. R. M. Kingma, A. J. H. Frijns, and W. D. van Marken Lichtenbelt, "Effect of local skin blood flow during light and medium activities on local skin temperature predictions," Journal of Thermal Biology, vol. 84, pp. 439-450, 2019.

[12] E. R. Nadel, R. W. Bullard, and J. A. Stolwijk, "Importance of skin temperature in the regulation of sweating," Journal of Applied Physiology, vol. 31, pp. 80-87, 1971.

[13] V. P. Saxena and D. Arya, "Unsteady state heat flow in epidermis and dermis of a human body," Indian Academy of Sciences (Mathematical Sciences), vol. 98, no. 1, pp. 71-80, 1998.

[14] D. B. Gurung, V. P. Saxena, and P. R. Adhikari, "FEM approach to one dimensional unsteady state temperature distribution in human dermal parts with quadratic shape function," Journal of Applied Mathematics \& Informatics, vol. 27, no. 1-2, pp. 301-313, 2009.

[15] S. Acharya, D. B. Gurung, D. B. Gurung, and V. P. axena, "Two dimensional finite element method for metabolic effect in thermoregulation on human males and females skin layers," Journal of Coastal Life Medicine, vol. 3, no. 8, pp. 623-629, 2015.

[16] R. W. Kenefick, S. N. Cheuvront, and M. N. Sawka, "Thermoregulatory function during the marathon," Sports Medicine, vol. 37, no. 4-5, pp. 312-315, 2007.

[17] M. A. Khanday and V. P. Saxena, "Finite element approach for the study of thermoregulation in human head exposed to cold environment," AIP Conference Proceedings, vol. 1146, pp. $375-385,2009$.

[18] M. Agrawal, K. R. Pardasani, and N. Adlakha, "Steady state temperature distribution in dermal regions of an irregular tapered shaped human limb with variable eccentricity," Journal of Thermal Biology, vol. 44, pp. 27-34, 2014.

[19] V. P. Saxena and M. P. Gupta, "Variational finite element approach to a heat flow problem in human limbs," International Journal of Mathematics and Mathematical Sciences, vol. 17, no. 4, pp. 771-778, 1994.

[20] B. Kumari and N. Adlakha, "One dimensional finite difference model to study temperature distribution in peripheral regions of a human body during and after exercise," Journal of Medical Imaging and Health Informatics, vol. 3, no. 2, pp. 179-186, 2013.

[21] P. R. Höppe, "Heat balance modelling," Experientia, vol. 49, no. 9, pp. 741-746, 1993.

[22] W. Perl, "Heat and matter distribution in body tissues and the determination of tissue blood flow by local clearance methods," Journal of Theoretical Biology, vol. 2, no. 3, pp. 201-235, 1962. 